\title{
OCCUPATIONAL BURNOUT IN HEALTH CARE - ANALYSIS OF SYSTEMIC AND ORGANISATIONAL RISKS AS WELL AS POSSIBLE PREVENTIVE ACTIONS
}

\section{Dorota Kwiatkowska-Ciotucha}

Wroclaw University of Economics and Business, Wroclaw, Poland e-mail: dorota.kwiatkowska@ue.wroc.pl

ORCID: 0000-0002-0116-4600

\section{Urszula Załuska}

Wroclaw University of Economics and Business, Wroclaw, Poland e-mail: urszula.zaluska@ue.wroc.pl

ORCID: 0000-0001-5305-8087

\section{Magdalena Ślazyk-Sobol}

The University of Wroclaw, Wroclaw, Poland e-mail: magdalena.slazyk-sobol@uwr.edu.pl

ORCID: 0000-0003-1165-0570

\section{Minna Lehesvuori}

South-Eastern Finland University of Applied Sciences (XAMK), Kouvola, Finland e-mail: Minna.Lehesvuori@xamk.fi

ORCID: 0000-0001-6935-1341

\section{Angelika Polak}

South-Eastern Finland University of Applied Sciences (XAMK), Kouvola, Finland e-mail: Angelika.Polak@xamk.fi

ORCID: 0000-0002-2168-0506

(C) 2019 Dorota Kwiatkowska-Ciotucha, Urszula Załuska, Magdalena Ślazyk-Sobol, Minna Lehesvuori, Angelika Polak

This is an open access article distributed under the Creative Commons Attribution-NonCommercial-NoDerivs license (http://creativecommons.org/licenses/by-nc-nd/3.0/)

DOI: 10.15611/eada.2019.4.04

JEL Classification: C59, M54

\begin{abstract}
The article presents the risk of occupational burnout observed in health care, as well as possibilities of prevention in this regard. Its authors used their knowledge and experience obtained during the implementation of the international Time2Grow project financed from the European Social Fund. The project was dedicated to developing a burnout prevention model mainly in the area of broadly understood health care. The project was implemented in the Polish-Belgian-Finnish partnership, thanks to which it provided great opportunities to benefit from good European practices.
\end{abstract}


The article presents the results of quantitative primary research carried out on Poland in the group of nurses and midwives, as well as selected results of quantitative and qualitative research conducted in Finland on a group of practicing nurses caring for elderly people.

Keywords: burnout prevention, health care, primary research results.

\section{Introduction}

The modern approach towards occupational burnout defines this phenomenon as a 'disturbed relationship' between the employee and their occupational environment [Maslach and Leiter, 2007, 2008, 2010, 2011]. What proves that this issue is so important is the extensive literature on the subject and the high social and organisational demand for the explanation of processes and phenomena affecting the effectiveness of employees as well as their mental well-being (Juczyński and Ogińska-Bulik, 2003; Ogińska-Bulik, 2006; Santinello, 2003, 2008, 2014; Schaufeli, 2004). The syndrome involves numerous dangers of an individual and social nature (decreased engagement in work, lower work efficiency, increased absence from work, somatic disorders, low professional satisfaction). Industries particularly at risk of occupational burnout are those which involve 'helping others', including health care. Unfortunately in Polish reality, occupational burnout is often still a taboo subject. Additionally, admitting that one experiences its symptoms is perceived as a weakness in many industries, the lack of organisational maturity and awareness of possible consequences for oneself and the institution. Observation of the contemporary Polish labour market indicates that the problem of occupational burnout is becoming worse every year. However, the scale of this phenomenon is difficult to determine due to the lack of current nationwide research in this area. ${ }^{1}$

The aim of the article is firstly to present the risks of occupational burnout observed in health care, and secondly to indicate possible prevention in this regard. The authors used their knowledge and experience obtained during the implementation of the international Time2Grow project ${ }^{2}$ financed from the European Social Fund, which was dedicated to developing a model of preventing occupational burnout mainly in the area of broadly understood health care. The project was implemented in the Polish-Belgian-Finnish partnership, owing to which it provided great opportunities to benefit from good European practices.

\footnotetext{
${ }^{1}$ There are only a few studies in the field of assessing the scale of occupational burnout and these include the research carried out by the team of Professor A. Bassam, a psychologist from the Institute of Psychology of the University of Kazimierz Wielki in Bydgoszcz, 2009.

${ }^{2}$ A transnational cooperation project POWR.04.03.00-00-W300/16 Time2Grow (Poland). Implementation period April 2017 - December 2019.
} 
Both Belgium and Finland are leaders in Europe in undertaking initiatives raising awareness of the consequences and prevention of occupational burnout. ${ }^{3}$

The aim of the article is achieved through analysis of the research results and presentation of the conclusions resulting from the activities undertaken in the project by the Polish and Finnish side. ${ }^{4}$ Due to the importance of occupational burnout issues in health care, the Polish project team conducted extensive quantitative primary research in a group of nurses and midwives. ${ }^{5}$ The Finnish partner, on the other hand, focused on this phenomenon among practicing nurses caring for elderly people, and relied on both quantitative and qualitative research methods.

\section{Literature review}

The most popular definition of occupational burnout in the world by Ch. Maslach and S. Jackson (Maslach, Jackson, and Leiter, 1996) was developed on the basis of many years of exploratory research based on interviews, surveys and observations of employees reporting disturbing symptoms. In light of this conceptualisation, it is defined as a set of three different psychological phenomena; it is psychophysical and emotional exhaustion and depersonalization expressed by impersonal interaction with recipients of professional services (in the latest organisational

${ }^{3}$ On the basis of European law, the legal background in the area of health and safety of employees (including in the field of preventive measures) is determined by Council Directive 89/391/EEC of 12 June 1989 on the introduction of measures to encourage improvements in the safety and health of workers at work (Journal of Laws L 183 of 29 June 1989, p. 1). Poland is one of the EU Member States which have limited the content of national legal acts to the minimum requirements of the Framework Directive. In Finland, the necessity of taking into consideration mental health of employees as part of health and safety at work is emphasised in legal acts in various ways. A pioneer in the field of occupational burnout prevention is definitely Belgian legislation, which on 1 September 2014 not only introduced the definition of psychosocial risks to the national legal order, but also imposed a number of obligations on employers to prevent their occurrence, including the obligation to create structures and employ experts involved in the assessment of their occurrence in the workplace. More information on legal issues can be found in: (Pachnowska and Zięba, 2019).

${ }^{4}$ The Polish project team consisted of employees and associates of Dobre Kadry Sp. z o.o. Research and Development Centre, whereas the Finnish one - employees of XAMK University.

5 The first primary research in the project was conducted in mid-2017 on a group of 153 respondents working in health care (64 nurses), education (46 teachers) and higher education sector (43 academic teachers). Two types of questionnaire forms were used in the study - LBQ Occupational Burnout Questionnaire and one prepared independently, aimed at assessing the recognition of the phenomenon among Polish employees. Due to the small size of the groups and the lack of random character of the selection of respondents, this study was used only as a pilot, without generalising the conclusions on the population. More information on the study results can be found in: (Załuska, Ślazyk-Sobol, and Kwiatkowska-Ciotucha, 2018, pp. 26-38). 
approach this attitude is referred to as cynicism) and reduced personal accomplishment defined as dissatisfaction with one's accomplishments and a reduced level of satisfaction with professional achievements. In the first empirical research, as a cause of occupational burnout one primarily indicated personal competencies of people working in occupations involving 'helping others', that is, mainly health care staff. Therefore they believed that the predictors of this phenomenon lay in interpersonal factors e.g. low psychological resilience, high neuroticism, excessive empathy (Juczyński and Ogińska-Bulik, 2003; Ogińska-Bulik, 2006). Nowadays, psychologists claim that burnout is an occupational problem and not a "personality defect or clinical syndrome" (Maslach and Leiter, 2011, p. 54). According to them, the cause of burnout is lack of harmony between a person and their work. The authors also grouped the causes of occupational burnout incusing excessive workload (a lot of activities to perform in a short period of time and with low resources), lack of control (inability to make decisions and choices), lack of reward, lack of recognition, a sense of injustice and conflicts of value (dissonance caused by difference between personal and company values). The state of "matching" between an employee and their work facilitates harmonious functioning, commitment and satisfaction with one's job. If, however, someone is not suitable for a given occupation, they suffer from stress which may accumulate and lead to occupational burnout. According to the researchers, organisations should treat the burnout problem seriously as it actually affects companies' performance. They point to the huge costs incurred by organisations due to burnout experienced by employees e.g. absence from work, sick leave, employee fraud, reduced performance and quality of work, greater damage and errors, abuse of psychoactive substances and mental illness of employees. The consequences of occupational burnout gain in significance in workplaces where employees experiencing this specific condition have direct contact with recipients of their services. Health care - both in Poland and abroad - is an industry always associated with emotional overload and high intensity of stressful stimuli (Ślazyk-Sobol, 2019). The main reason for this is direct contact with patients and people under their care who are in pain, who suffer and who cannot always be helped. This industry is also very diverse - the research within the Time2Grow project covered employees involved in the care and support of disabled people, surgical and oncology nurses, anaesthetists nurses and carers of terminally ill patients in hospices. Daily contact with sick, disabled, suffering or dying patients and their families exhausts the emotional resources of employees who often lack institutional support and are not able to cope with difficult situations and traumatic experiences. The primary research carried out as part of the Time2Grow project confirms that Polish employees from the healthcare industry work in several places at the same time for financial reasons. The low remuneration imposes the need for additional earning in hours intended for family and private life. Lack of free time, 
psychophysical strain and permanent physical and emotional effort at work are additional factors leading to occupational burnout of this group. For this reason, researching the opinions and feelings of employees in the field of the social perception of occupational burnout, the possible preventive actions as well as the main factors putting the psychophysical well-being of employees in this sector at risk, has become the main goal of research and practical solutions offered in the Time2Grow project.

\section{Own research}

The Polish team prepared independently its own questionnaire for quantitative research (PAPI) with questions concerning selected aspects of employment and occupational burnout. The research was carried out in the period of October 2018-March 2019, with the support of the Lower Silesian Chamber of Nurses and Midwives and people in managerial positions in individual health care units. Eventually, the questionnaire was completed by 632 nurses and midwives working in hospitals in Silesia and Lower Silesia.

The research was of an exploratory nature and its main purpose was to learn about the social perception of the phenomenon of occupational burnout, its causes, consequences and effective preventive measures in a group of professionally active nurses. The questionnaire form consisted of 12 closed-ended questions with a cafeteria of answers provided in it. The questions were formulated in such a way that the respondent, depending on the character of a question, had to choose one answer, multiple answers (giving a specific number of answers) or evaluate the level of occurrence of a given factor (on a 11-point scale, from 0 to 10). The issues raised in the questionnaire concerned e.g. the specificity of work and commitment to its performance, understanding of occupational burnout and its symptoms, the possibilities of preventing this phenomenon and the effectiveness of various solutions in this area, and evaluation of the of risk of occupational burnout in the profession of a nurse and midwife.

The structure of the research sample is presented in Figure 1. Of the research participants $94 \%$ were women, which is consistent with the employment structure in Poland in the case of mid-level medical staff, while $16 \%$ of respondents held managerial functions. The largest group was the one consisting of respondents aged $46-55$ (42\% of respondents) and a group of people with over 25 years of work experience $(53 \%)$.

The research carried out in Finland focused primarily on evaluating well-being at work as a major factor in preventing occupational burnout. The findings and conclusions presented in the article are the result of two studies and observations from workshops with the use of the simulation pedagogy method (Keskitalo, 2015; Salakari, 2010). The first study was carried out over the period of June to August 
2017 and was based on the focused interview method, in which 15 interviews were conducted with employees of local university partners: Elimäen Puustelli, Valkealan Iltatähti and Kymijoen Hoiva. These partners are private organisations which provide services improving the daily life and well-being of the elderly and disabled, such as ensuring safe housing, rehabilitation, recreation, nutrition, meetings, etc.

Sex

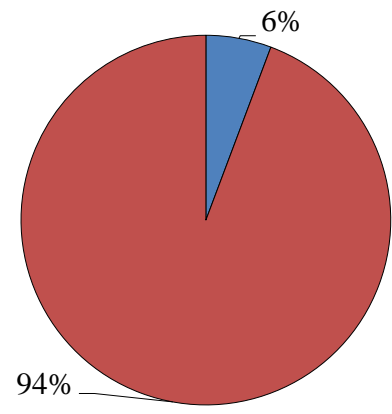

$\square$ male $\square$ female

Current job post

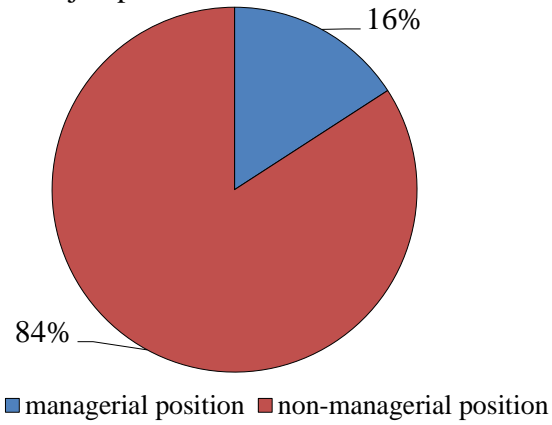

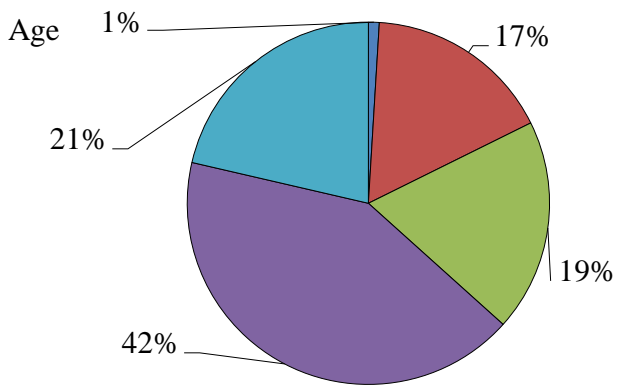

$\square 25-35$ years old $\square 46-55$ years old

$\square 25$ years old or les $\square 36-45$ years old $\square 56$ years old and more

Seniority

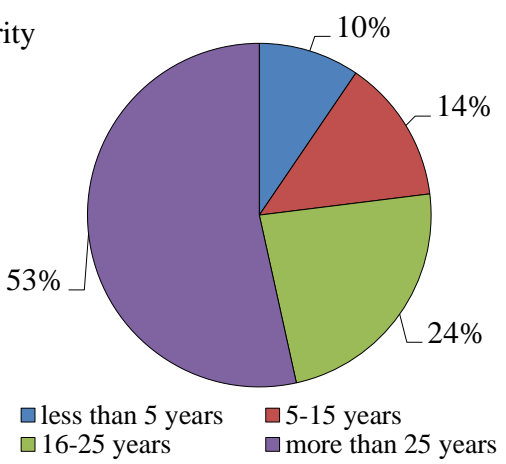

Fig. 1. Research sample - metrics features

Source: own calculations.

The subjects of the interviews concerned the meaning of the work, integration, stress and factors that help to cope with workload. The aim of the study was to answer the following questions:

1) How do employees of nursing services feel about the relevance of their work?

2) How do employees of nursing service experience interactions in their work community?

3) What are the strengths and weaknesses of coping with the workload in nursing services? 
The interviews were recorded and written down, then the written text was analysed using the content analysis method.

The second study was carried out in the period of February-March 2018. Its aim was to gather information on the well-being of employees of three small-sized healthcare providers partners. The study used the Abilitator Model $^{6}$ modified questionnaire form which contained closed questions with possible answers on the Likert scale (from 1 to 5) and complementary open questions. The respondents evaluated their interpersonal skills as well as current and future ability to work (in a two-year period). The questionnaire form was completed by 67 study participants (from the total number of 120 employees $-56 \%$ of questionnaire forms were filled in). The majority of respondents (70\%) were people working directly with patients, whereas the remaining part included employees holding managerial positions (12\%) and support staff (18\%). The most numerous group was the one with people aged 40-53, whereas one in four respondents were over 53 years old.

The simulation workshops were carried out in the Time2Grow project to highlight and analyse challenging situations in nursing, to find new and workable solutions, to increase participants' self-knowledge, and to develop collaboration and interaction skills. The simulation workshops were about gathering information. Based on the theme interview and its analyses, the above themes were brought to the simulation workshops, and case scenarios were created for each workshop. Each scenario was discussed in one to two workshops. Feedback from the participants of the workshops was always utilized in the preparations for the next meeting. In total 14 workshops of this type were conducted.

\section{Discussion of results}

\subsection{Questionnaire surveys carried out in Poland}

The first of the analysed characteristics was the specificity of the work. The respondents evaluated the statements on a 0-10 scale, where 0 meant that a given statement did not match their work, whereas 10 - that it definitely did. Among the distinguished statements there were some negative (e.g. little success at work, too much bureaucracy) and positive ones (e.g. job satisfaction, suitability of the job performed). In the article the authors focused on determining negative factors, meaning those whose severity may cause a decline in commitment to work and, in consequence, lead to the risk of occupational burnout. Figure 2 presents the average evaluations for individual factors, ordering them according to the degree of matching one's job. In the opinion of the respondents, the most serious problem is the excess of bureaucracy (average evaluation 7.58), followed by: high emotional

6 More information about the Abilitator Model can be found on: https://sivusto. kykyviisari.fi/en/the-abilitator-model/. 
stress (6.58), great physical strain (6.23) and excessive workload (the need to rest from it, 6.20). Among the negative factors distinguished in the questionnaire, the lowest evaluations (below 5) were noted for stressful relationships with co-workers and supervisors.

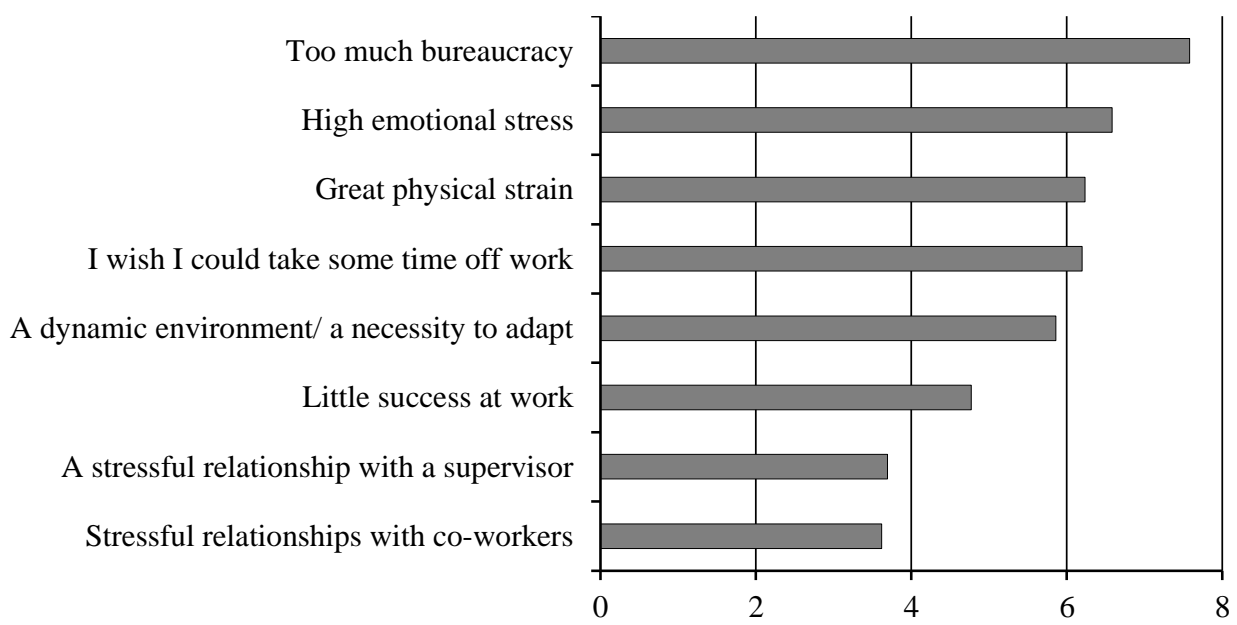

Fig. 2. Negative factors characterising work - average evaluations

Source: own calculations.

The effect of adverse factors in the work environment may be reluctance to perform it. Figure 3 depicts the distribution of answers to the question about the feeling of reluctance to go to work, in which respondents could choose one of five answers (from "never" to "constantly"). The most frequently indicated option was "occasionally" ( $43 \%$ of respondents), and $40 \%$ of respondents feel reluctance "very rarely", whereas the remaining $17 \%$ "often" or "constantly".

In order to identify the key negative factors determining reluctance to work a logistic regression was used (SPSS, ver. 25). The results of the answer to the question concerning reluctance to work which the respondents felt, served as a dependent variable. From the collection of data the authors eliminated observations for which the selected answer category was "occasionally" not indicating clearly any favourable or unfavourable situations in this area (the number of remaining observations for analysis $n=345$ ). The remaining results were gathered into two categories: 0 - the respondent does not generally feel the reluctance to work (answers "never" and "very rarely"), 1 - the respondent feels the reluctance to work (answers "often" and "constantly"). The set of potential explanatory variables included answers to the question about the negative factors characterising their work. In order to find a model that would be significant from the point of view of $F$ statistics (the Wald test), the stepwise logistic regression method was used. The 


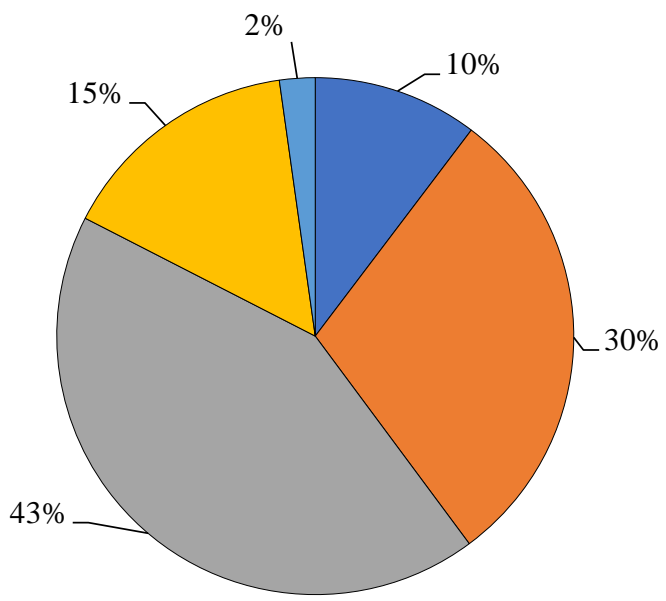

$\square$ Never $\square$ Very rarely $\quad \square$ Occasionally $\quad \square$ Often $\quad \square$ Constantly

Fig. 3. Feeling of reluctance to go to work

Source: own calculations.

critical value of the $F$-statistics was at the significance level $\alpha=0.05$ during forward selection, and $\alpha=0.10$ during backward elimination. In order to check whether the model matches the empirical data both the Nagelkerke and Hosmer-Lemeshow tests were used. The latter compares the model used to the zero model (only with an intercept parameter) in terms of relevance of the classification (see: (Gruszczyński, 2002; Heckman and Leamer, 2001)). The Nagelkerk $R^{2}$ value for the model was 0.562 , whereas the accuracy of qualification - over $85 \%$. The following factors were included in the model - differential statements (in the order of introduction to the model).

Table 1. Factors in the model

\begin{tabular}{|l|c|c|c|c|c|c|}
\hline \multicolumn{1}{|c|}{ Factor } & $B$ & $\begin{array}{c}\text { Standard } \\
\text { error }\end{array}$ & Wald & df & $p$-value & Exp(B) \\
\hline I wish I could take some time off work & 0.605 & 0.074 & 67.446 & 1 & 0.000 & 1.830 \\
\hline A stressful relationship with a supervisor & 0.168 & 0.055 & 9.462 & 1 & 0.002 & 1.183 \\
\hline High emotional stress & 0.165 & 0.048 & 11.919 & 1 & 0.001 & 1.179 \\
\hline
\end{tabular}

Source: own calculations.

Excessive workload (the need to rest from work) has the greatest impact on reluctance to work. An increase by one unit of the evaluation value for the factor characterising one's work increases the risk of reluctance to work by over $80 \%$. The next two differentiating factors increase this risk by $18 \%$ (in the case of one 
unit change for the factor evaluation). It is worth noting the fact that while stressful relationships with the supervisor have not been evaluated as a serious problem in the workplace, their occurrence significantly affects personal attitude to work.

When analysing the issues related to the risk of occupational burnout, and above all the possibilities of preventing this phenomenon, it is a good idea to determine the understanding and awareness of its occurrence among staff. Greater understanding and awareness of occupational burnout undoubtedly make it easier to talk about it in the organisation or introduce preventive programs. Figure 4 presents the results of the subjective evaluation performed by the respondents in the area of understanding and skills to recognise occupational burnout symptoms. The $0-10$ scale was used, where 0 meant lack of understanding/skills, whereas 10 - possessing such understanding/skills. The respondents assessed whether their knowledge of occupational burnout was sufficient and whether they were able to recognise the symptoms of occupational burnout in themselves and other employees. The average evaluation for all three issues is high (above 7), which means that in their subjective assessments, the respondents know quite a lot about occupational burnout and how to recognise it. The understanding itself gained the highest evaluation, followed by the ability to recognise this phenomenon in oneself and also other people.

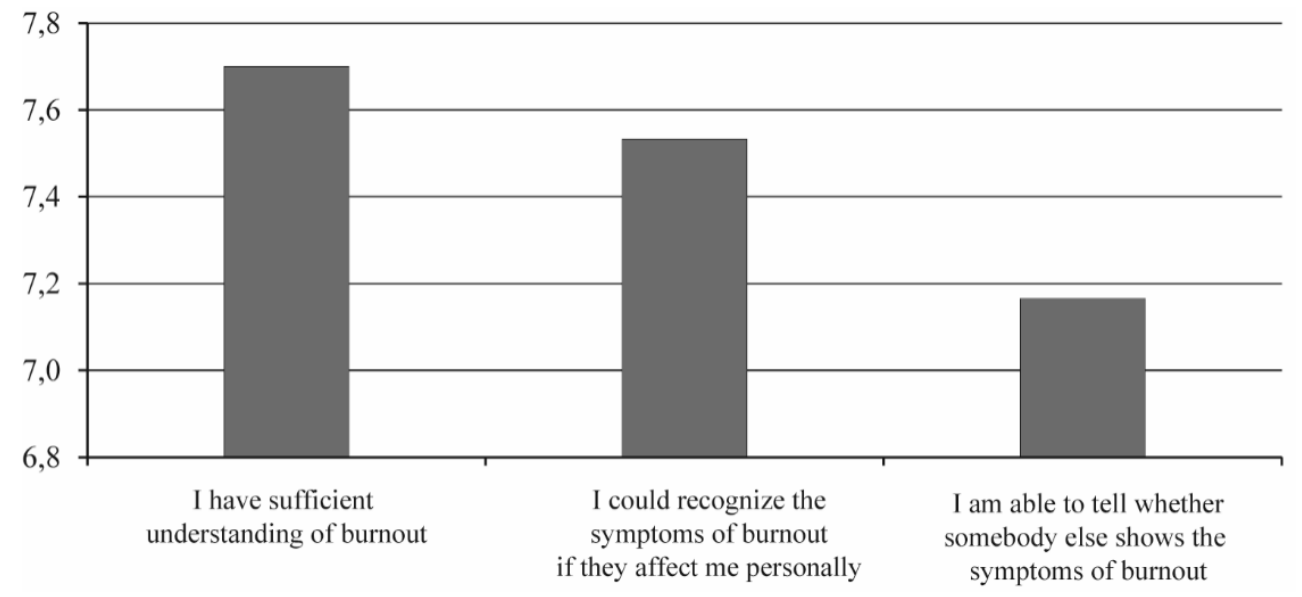

Fig. 4. Understanding of occupational burnout - a subjective assessment

Source: own calculations.

The respondents were also asked to evaluate which of the symptoms listed in the questionnaire form characterise a person suffering from occupational burnout. Figure 5 shows the numbers for specific features indicated only by those people $(n=377)$ who evaluated their knowledge of occupational burnout in a very positive way $(8-10)$. Those features are presented in the order from the most to the least frequently chosen. 


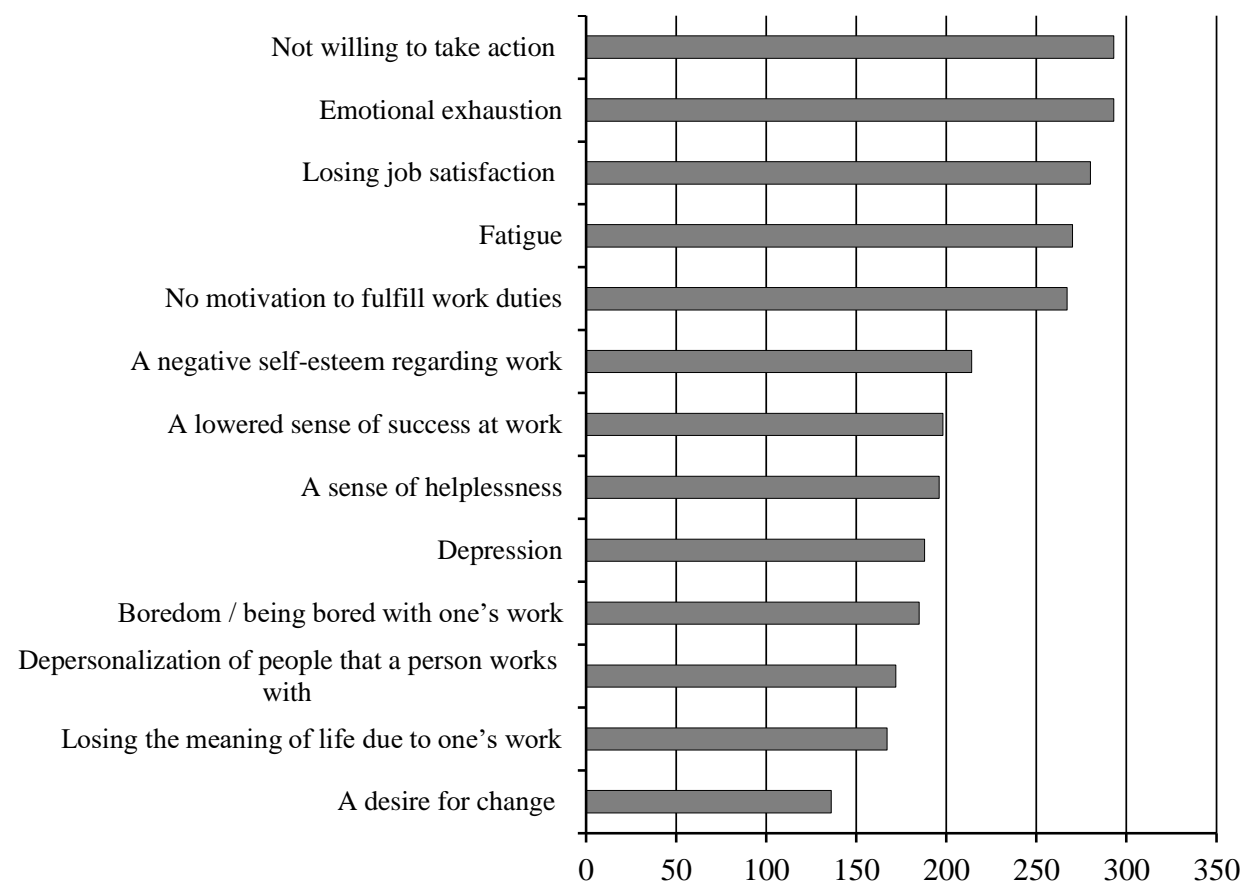

Fig. 5. Symptoms characterising an occupationally burnt-out person according to the respondents declaring high awareness of this phenomenon

Source: own calculations.

The symptoms characterising a person suffering from occupational burnout, which the respondents indicated most frequently, include unwillingness to take action and emotional exhaustion (78\%), the loss of job satisfaction (74\%), fatigue (72\%) and lack of motivation to fulfil work duties (71\%). Less than half of the respondents reported symptoms such as a desire for change (36\%), losing the meaning of life due to one's work (44\%), depersonalisation of the people they work with - patients (46\%) - being bored with one's work (49\%).

Figure 6 presents the average evaluations of respondents regarding burnout as a problem in health care. They concerned two aspects:

1. How serious is occupational burnout? (answers on a 0-10 scale, where $0-$ it is not a problem, $10-$ it is a very serious problem).

2. How easy would it be to admit occupational burnout in the workplace? (answers on a 0-10 scale, where 0 - very easy, 10 - very difficult).

According to the respondents, occupational burnout is a serious problem in health care (average evaluation: 8). It is worth noting that more than $40 \%$ of respondents marked 10 on the scale claiming that this problem is very serious, and nearly $70 \%$ chose $8-10$. Admitting occupational burnout in the workplace was 
thought to be a less problematic issue (with an average evaluation of 6). When answering this question, most respondents selected 5 (26\%), whereas the remaining ones -10 and 8 (16\% and $15 \%$, respectively).

Burnout as a serious problem in the workplace

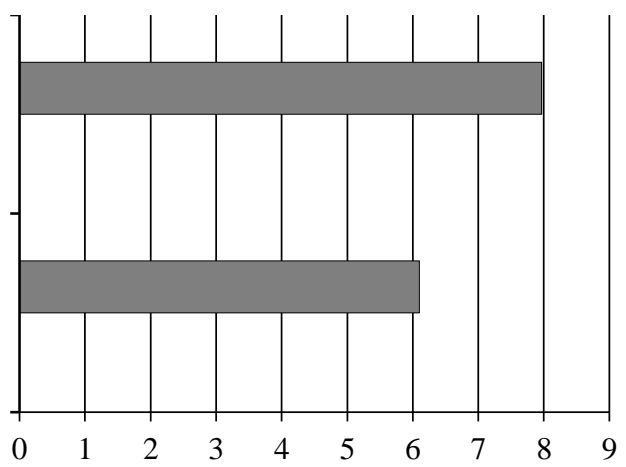

Fig. 6. A problem of occupational burnout in the workplace and difficulty admitting its symptoms Source: own calculations.

It should be emphasised that Polish respondents representing the health care industry very accurately diagnosed the axial symptoms of occupational burnout (Maslach and Leiter, 2008, 2010; Schaufeli, 2004; Sęk, 2004), which proves that this group is very well educated. Practical activities (workshops, self-development groups) implemented as part of support for this occupational group in the Time2Grow project provided the authors of the article with insights on the high awareness of nurses in the context of risks in the work environment. During many years of their education, nurses often confront the issues connected with taking care of one's mental health. As a result, they can accurately describe a profile of a person experiencing the process of occupational burnout. They notice the significance of the problem because they find themselves in different and difficult situations generating additional mental strain on a daily basis. However, this does not mean that they are able to take adequate and individual measures preventing occupational burnout, or that they can seek professional psychological help in an effective way.

An interesting result is the willingness of nurses to admit experiencing symptoms of burnout. The percentage presented above shows that admitting own professional problems is moderately difficult for Polish nurses, while in a completely different industry - education - issues related to the experience of occupational burnout seem to be a taboo subject (Załuska, Ślazyk-Sobol, and Kwiatkowska-Ciotucha, 2018). In this context, nurses seem to be more self-aware, open to sharing their own emotional states with others, and assuming that the ease of sharing one's experiences with others may also mean the willingness to work on 
oneself, nurses are much more eager to take various actions supporting their mental well-being; $77 \%$ of respondents have many years of professional experience (even more than 16 years). The results of global empirical research (Maslach and Leiter, 2010, 2011; Santinello, 2008, 2014) indicate that people with a shorter work experience are most at risk of occupational burnout, which results from a less developed ability to effectively cope with difficult professional situations. Less experienced employees appear to be more vulnerable in the work environment. This may result from a slightly weaker insight into the area of one's own strengths and weaknesses requiring further development and a higher level of occupational stress experienced. The majority of the research sample were experienced nurses, which certainly influenced the results, probably indicating the greater awareness and maturity of medical staff in terms of perceiving and understanding the essence of occupational burnout.

Additionally, one checked the presence of a relationship between the two evaluations - the significance of the problem and the difficulty of admitting it. Figure 7 shows the correlation graph of the answers for these two evaluations. The distribution of points suggests that there is no such relationship (in the form of a 'cloud'), but this is due to the abrupt nature of the possible answers (a discrete variable). The Chi-squared test indicates the existence of a linear relationship

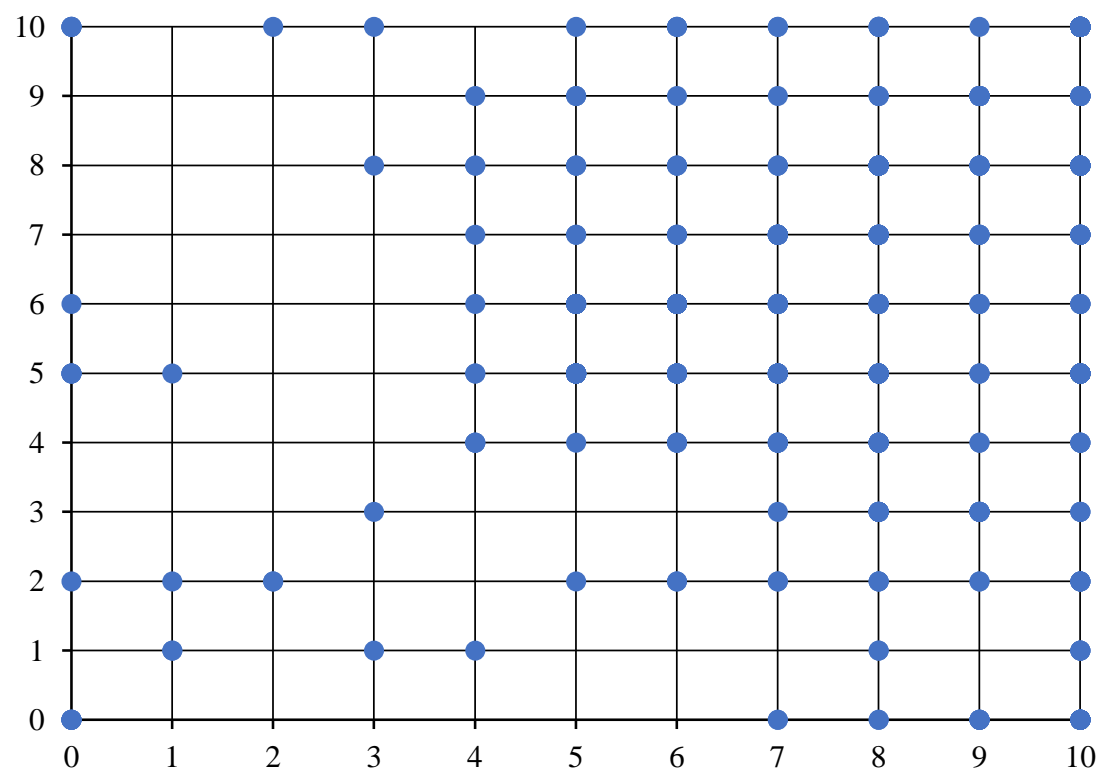

Fig. 7. Dependence between the evaluation of the importance of the occupational burnout problem in the workplace (horizontal axis) and the difficulty in admitting it (vertical axis)

Source: own calculations. 
between both features (for significance level $\alpha \leq 0.001$ ). This means that the assessment of occupational burnout as a serious problem is accompanied by the assessment of the greater difficulty in admitting it. Apparently this is not only a serious problem in the entire industry - a lot depends on the organisational culture and feelings of individual employees. Perceiving occupational burnout primarily as a problem of an individual rather than of a socio-organisational system may generate greater resistance in the researched group to interpreting burnout symptoms as possible to overcome, and thus - to a greater willingness to discuss this topic and implement remedial actions.

The last of the issues analysed was the respondents' opinion on the possibility of preventing burnout in health care and the solutions which would be helpful in that. Figure 8 depicts the distribution of answers to the question about prevention possibilities. The range of answers for this question included "definitely yes", "definitely no", and the "difficult to say" option. According to $47 \%$ of respondents, it is possible to prevent occupational burnout ("definitely yes" and "rather yes"), $22 \%$ had no opinion in this respect ("difficult to say"), whereas the remaining $31 \%$ are "rather" or "definitely" sceptical when evaluating the possibilities of preventive measures.

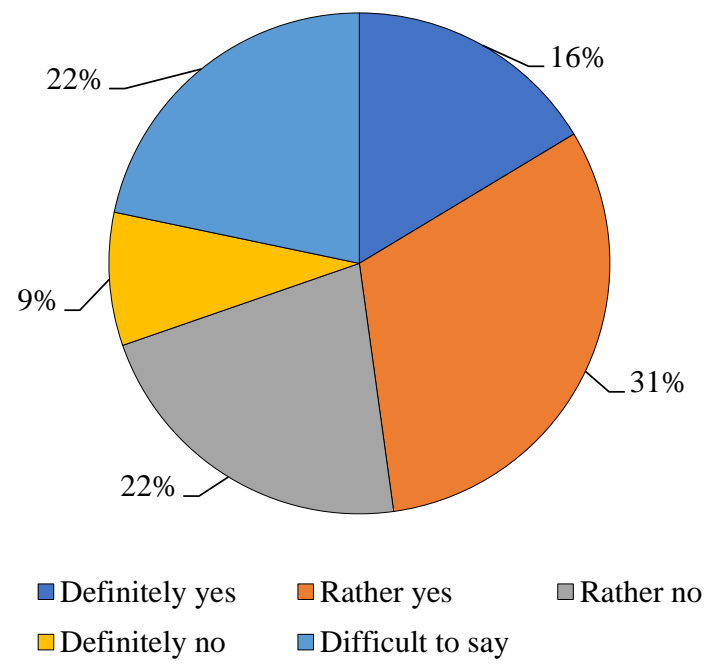

Fig. 8. The evaluation of the possibilities of occupational burnout prevention in health care

Source: own calculations.

The proposals for solutions which can help prevent occupational burnout and which were listed in the questionnaire form were evaluated on the 0-10 scale, where 0 means "definitely not helpful", whereas 10 - "definitely helpful". The average evaluation was presented in Figure 9. According to the respondents, the 
most effective solutions include access to a psychologist or therapist that helps employees manage stress/problems ad hoc (average evaluation 7.7) and qualifying burnout as an occupational disease (average evaluation 7.5). Introducing a position of a "confidant" that employees could contact if the need arises was thought to be less effective (average evaluation 4.7). The choices of the nurses participating in the research reflect the evaluated activities as recommended. The conducted analysis does not show, however, whether they are also their most preferred preventive measures. What might indicate their potential effectiveness is the evaluation of individual work with a psychologist (a therapist). The nurses indicate as the most effective specific processes and activities, which reflects a certain tendency of this professional group, i.e. the active monitoring of the source of stress and task-oriented approach to solving difficult situations at work (Schaufeli, 2004).

Access to psychologist or therapist who helps the employees in managing the stress / problems ad hoc

Qualifying burnout as an occupational disease

Special training for employees showing first symptoms of burnout

Organizing additional leisure activities, (e.g. sports) Introducing career change support programmes in case of burnout

Changing the organizational culture

Team-building events

Supporting employees in regular monitoring the first symptoms of burnout

Support groups

Implement information on burnout into education policies (school, studies)

Support of an employment counsellor before commencing work

Special training before commencing work

Introducing a post of a "confidant" that employees could contact if the need arises

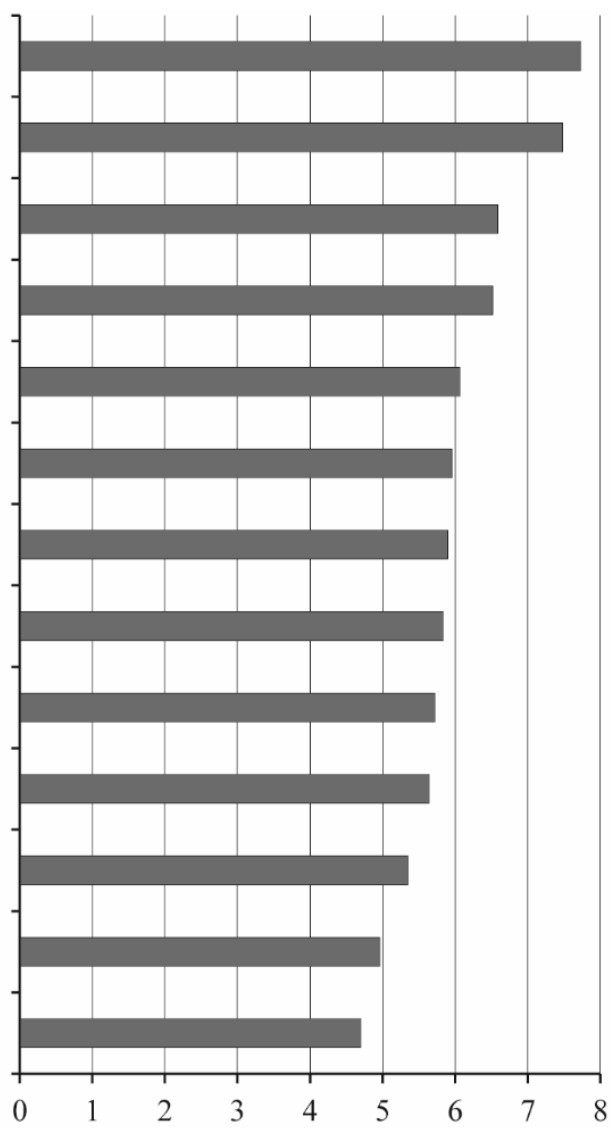

Fig. 9. Effectiveness of solutions helpful in occupational burnout prevention Source: own calculations. 


\subsection{The research conducted in Finland}

The respondents participating in quantitative research perceive nursing care as both physically and mentally demanding. In general, they evaluated their current and future resources in both fields in a positive way. It is worth emphasizing that age was not considered a factor significantly affecting ability to work. It only appeared in the answers to open questions, which was primarily associated with increased physical ailments, but its role in a working capacity was not seen as significant. The respondents also positively rated their own resources in the context of their occupation - older employees (over 54 years old) evaluated their mental resources necessary for effective work higher than younger ones. Differences could also be observed between people with different levels of education. Own skills and the ability to work were better evaluated by the respondents with a higher education, and less by those with a secondary school education.

Most respondents believe that they will be able to work in their current profession for the next two years. According to the respondents' evaluation, they are able to maintain a work-life balance, and enjoy a normal and everyday life quite often or very often. Areas which were assessed well, but which still require improvement, include the culture of conversation at work, communication and interaction skills (own and also in a group of co-workers), as well as cooperative skills. Similar evaluations also concerned the ability to listen to others in the workplace and to be heard and understood, the ability to express different emotions and raise difficult problems in the workplace. On the whole, there are no problems with the flow of information in the workplace. The employees share the necessary information with each other, and they can rely on the help of their colleagues if they need some advice on working with customers.

The respondents expect changes primarily in the area of receiving regular feedback, especially from the supervisor, but also from their colleagues. In their opinion, communication imperfections resulting from negative attitudes and personality traits are also a challenge. What is also worth emphasising is that the respondents believe that well-being in the workplace depends on both parties - the employer and the employee. Everyone should be involved, motivated to self-development and improve their work results. While answering the question about future plans, the respondents often mentioned their plans related to work and career development.

The structured interviews allowed, among others, to identify the topics of workshops aimed at improving employees' functioning in the workplace. The topics were developed individually for a group of people holding managerial positions (supervisors) and those working directly with customers. In the case of supervisors, it was considered necessary to improve competences in areas such as personal performance discussions and giving feedback. For the second group 
of employees, this concerned in particular such issues as medication errors (mistakes), reporting of death to close friends and relatives, influencing one's own work, dreams, challenging situations at work, guiding a newcomer to work routines and challenges in the employee's private life.

The workshops conducted with the use of the simulation pedagogy method were evaluated as a positive experience. Their purpose was described by the participants mainly as improving well-being at work, improving the atmosphere in the work environment as well as interaction skills. This means that the method used can effectively influence the development of well-being at work and can be an effective tool for preventing occupational burnout.

Important results of research and workshops were also new ideas for developing the well-being of employees in the workplace. Based on the observations of the participants (nurses wrote about their emotions in a pocket notebook every day for the whole week while being at work, including positive and negative emotions and related situations), appropriate workshops were designed. According to the needs' analysis in this respect, the topics of the workshops focus on the following issues: introduction to the variety of emotions that we all experience and how they affect our behaviour and communication, introduction to the well-being at work framework theory, practical exercise in groups on how one deals with one's own emotions at work. The aim of the workshops is to learn how to manage one's own emotions, acquire skills of distinguishing situations which one can influence and control, and those which cannot be either influenced or controlled, but which one must be able to deal with and forget about as soon as they can.

\section{Conclusions}

The results of the quantitative research carried out among Polish nurses are consistent with current global empirical studies concerning occupational burnout predictors (Cherniss, 1980, 1992, 1995; Maslach and Leiter, 2008). What we know about occupational burnout thanks to numerous psychological research means that it is a universal experience for members of all professions since it concerns the relationship that connects people with the work they do. The characteristics of jobs, the types of occupational situations which the respondents deal with, as well as service recipients, are different. However, disappointment at work, a sense of emotional exhaustion, distance, coldness and indifference, as well as reduced effectiveness of performed tasks, are increasingly frequent experiences of social service occupations. Unfortunately these experiences may rapidly evolve, weaken or intensify if we do not modify our activities with any preventive strategy. As the most frequent causes of occupational burnout, Polish 
nurses indicated bureaucracy, excessive workload and stress. In this respect, this occupational group is not particularly different from other industries. What seems to be an important issue characterising nurses in a certain way is their high readiness to discuss the topic of occupational burnout in the work environment, and therefore the relatively great ease of admitting the symptoms experienced and awareness of the symptoms and characteristics of this phenomenon. Due to the extremely difficult situation of the nursing profession in Poland, this group should be particularly supported, taking into account not only the systemic and organisational factors such as balancing financial deficits, adequate workload and duties, reduction of administrative tasks in the workplace and greater social support. Nurses are a professional group representing high openness to the implementation of practical preventive models, which is demonstrated by testing the Time2Grow model among members of this industry, both in Poland and Finland. It is also worth emphasizing that, according to the results of research carried out in Finland, developing interaction and a sense of commitment are essential for well-being at work, therefore it is worth conducting development activities in this area. As the Finnish experience shows, simulation pedagogy is a good method of training and conducting workshops in the field of occupational burnout prevention. Moreover, experienced health care staff evaluate their own psycho-emotional resources and perceive systemic and organisational risks contributing to the phenomenon of occupational burnout in a similar way to the Polish employees. What in the group of Finnish nurses was indicated as "areas requiring improvement" in the prevention of occupational burnout, the Polish respondents defined as the organisational culture of the workplace. Changing the organisational culture and building (integrating) an employee team was, in the opinion of the Polish respondents, an effective way to prevent burnout. Considering the cultural differences, the different socio-economic situation and, above all, the differences in the professional status of nurses from Poland and Finland, one should emphasise that despite this, elementary and perhaps priority actions reducing psychological labour costs are similar in both groups. Regardless of the dividing differences, health care professionals need open and clear intra-organisational communication, a culture of systematic feedback, and better quality teamwork. These activities, although they seem simple and relatively easy to implement, create real difficulties for employees and employers of modern health care institutions. 


\section{Bibliography}

Cherniss, C. (1980). Staff burnout. Job stress in the human services. Beverly Hills, CA: Sage Publications.

Cherniss, C. (1992). Long-term consequences of burnout. An exploratory study. Journal of Organizational Behaviour, (13), 1-11.

Cherniss, C. (1995). Beyond burnout: Helping teachers, nurses, therapists and lawyers recover from stress and disillusionment. New York: Routledge.

Gruszczyński, M. (2002). Modele i prognozy zmiennych jakościowych $w$ finansach $i$ bankowości. Warszawa: Wydawnictwo SGH.

Heckman J., and Leamer E. (2001). Handbook of econometrics, vol. 5. Amsterdam: Elsevier.

Official Journal of the European Communities (Luxembourg), L 183, 29 June 1989.

Juczyński Z., and Ogińska-Bulik N. (2003). Zdrowie najważniejszym zasobem człowieka. In Z. Juczyńki, N. Ogińska-Bulik (Eds.), Zasoby osobiste i społeczne sprzyjające zdrowiu jednostki (pp. 9-16). Łódź: Wydawnictwo Uniwersytetu Łódzkiego.

Keskitalo, E. (2015). Developing a pedagogical model for simulation-based healthcare education. Acta Universitatis Lapponiensis, (299).

Maslach Ch., Jackson S.E., and Leiter M. (1996). MBI manual. 3rd ed. Mountain View, CA: CPP, Inc.

Maslach, Ch., and Leiter, M.P. (2007). Burnout. In G. Fink (Ed.), Encyclopedia of stress (pp. 368-371). New York: Elsevier.

Maslach, Ch., and Leiter, M.P. (2008). Early predictors of job burnout and engagement. Journal of Applied Psychology, 93(3), 498-512.

Maslach, Ch., and Leiter, M.P. (2010). Pokonać wypalenie zawodowe. Sześć strategii poprawiania relacji z praca. Warszawa: Oficyna Wolters Kluwer business.

Maslach, Ch., and Leiter, M.P. (2011). Prawda o wypaleniu zawodowym. Co robić ze stresem $w$ organizacji. Warszawa: Wydawnictwo Naukowe PWN.

Ogińska-Bulik, N. (2006). Occupational stress and its consequences in healthcare professionals: The role of type D personality. International Journal of Occupational Medicine and Environmental Health, 19(2), 113-122.

Pachnowska, B., Zięba, M. (2019). Wypalenie zawodowe - zapobieganie $i$ przeciwdziałanie. Poradnik dla pracodawców. Wrocław: Dobre Kadry. Centrum Badawczo-Szkoleniowe Sp. z o.o.

Salakari, H. (2010). Simulaattorikouluttajan käsikirja. Helsinki: Hakapaino Oy.

Santinello, M., Dallago, L., Dal Ponte, A., and Fontana, F. (2003). Gestire lo stress nelle organizzazioni: L'esperienza dell'Azienda sanitaria provinciale trentina, Tendenze Nuove, (1), 45-66.

Santinello, M. (2008). LBQ Link burnout questionnaire. Manuale. Firenze: Giunti O.S. Organizzazioni Speciali.

Santinello, M. (2014). LBQ. Kwestionariusz wypalenia zawodowego. Podręcznik. Warszawa: Pracownia Testów Psychologicznych Polskiego Towarzystwa Psychologicznego.

Schaufeli, W.B. (2004). Ocena skuteczności warsztatu radzenia sobie z wypaleniem dla pielęgniarek. In H. Sęk (ed.), Wypalenie zawodowe. Przyczyny i zapobieganie (pp. 216-235). Warszawa: Wydawnictwo Naukowe PWN.

Ślazyk-Sobol, M. (2019). Jak sobie radzić w wypaleniem zawodowym. Poradnik dla pracowników. Dobre Kadry. Wrocław: Centrum Badawczo-Szkoleniowe Sp. z o.o.

Załuska, U., Ślazyk-Sobol, M., and Kwiatkowska-Ciotucha, D. (2018). Burnout and its correlates an empirical study conducted among education, higher education and health care professionals, Econometrics. Advances in Applied Data Analysis, 22(1), 26-38. 


\section{WYPALENIE ZAWODOWE W OPIECE MEDYCZNEJ - ANALIZA ZAGROŻEŃ SYSTEMOWO-ORGANIZACYJNYCH ORAZ MOŻLIWYCH DZIALAŃ PREWENCYJNYCH}

Streszczenie: W artykule przedstawiono zagrożenia związane ze zjawiskiem wypalenia zawodowego obserwowane w opiece medycznej, wskazano również możliwości prewencji w tym zakresie. Wykorzystano wiedzę i doświadczenie zdobyte przez autorki w trakcie realizacji międzynarodowego projektu Time2Grow - finansowanego ze środków Europejskiego Funduszu Społecznego. Projekt miał na celu wypracowanie modelu prewencji wypalenia zawodowego, głównie w obszarze szeroko pojętej opieki medycznej. Projekt realizowany był w partnerstwie polsko-belgijsko-fińskim, dzięki czemu dawał duże możliwości korzystania $\mathrm{z}$ dobrych europejskich praktyk. W artykule przedstawiono wyniki ilościowych badań pierwotnych przeprowadzonych w Polsce na grupie pielęgniarek i położnych oraz wybrane wyniki badań ilościowych i jakościowych prowadzonych w Finlandii wśród opiekunów osób starszych.

Słowa kluczowe: prewencja wypalenia zawodowego, opieka medyczna, wyniki badań pierwotnych. 